\title{
RadioDoc Review
}

Volume 3 | Issue 2

Article 10

December 2017

CALL OUT for CREATIVE AUDIO FEATURES for CRITIQUE And ANALYSIS in RadioDoc Review Issue 7, 2018

Laura Romero

www.radioimaginamos.org, lauraromerovall@gmail.com

Follow this and additional works at: https://ro.uow.edu.au/rdr

Recommended Citation

Romero, Laura, CALL OUT for CREATIVE AUDIO FEATURES for CRITIQUE And ANALYSIS in RadioDoc Review Issue 7, 2018, RadioDoc Review, 3(2), 2017.

Research Online is the open access institutional repository for the University of Wollongong. For further information contact the UOW Library: research-pubs@uow.edu.au 


\title{
CALL OUT for CREATIVE AUDIO FEATURES for CRITIQUE And ANALYSIS in RadioDoc Review Issue 7, 2018
}

\begin{abstract}
Next issue of RadioDoc Review (Issue 7, 2018) will be guest edited by me, Laura Romero - and I am calling for nominations of audio works in languages OTHER THAN ENGLISH to be considered for in-depth review. See article for guidelines. Submit by 1 April 2018.
\end{abstract}




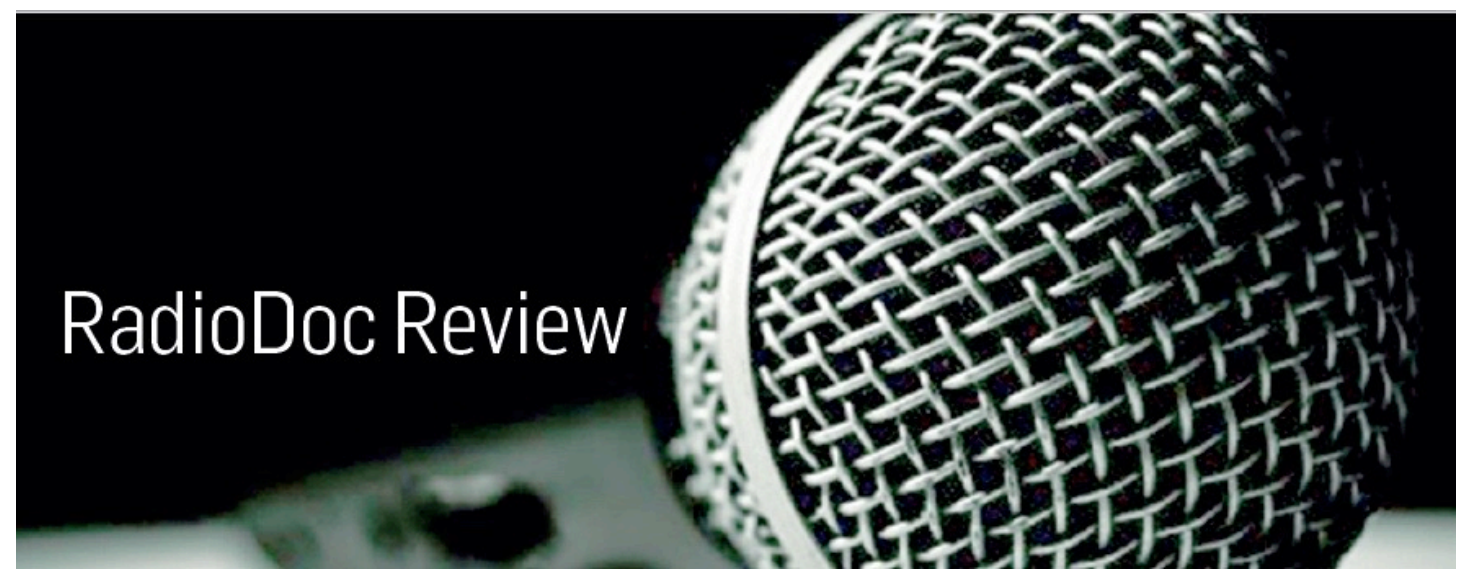

\section{CALL FOR CREATIVE AUDIO FEATURES for CRITIQUE AND ANALYSIS}

\section{LANGUAGES OTHER THAN ENGLISH PREFERRED}

EMERGING PRODUCERS WELCOME fOr SPECIAL MULTILINGUAL EDITION Of RADIODOC REVIEW

In 2018, RadioDoc Review is turning its critical ears on audio features in languages OTHER than English. Yes, we've critiqued works in French, Norwegian, Farsi, German and Polish - but the majority of the audio documentaries, features and podcasts we've analysed have been in English.

This issue, I'm taking over. Hello, I'm Laura Romero, based in Valencia, Spain. I work for media as sound producer. I also give specialised workshops on sound documentary and radio art in many universities. I founded the Spanish online review Radioimaginamos.org. I also research crafted audio narratives (my PhD examined the power of the use of spatial elements in audio fiction stories). But I also love to MAKE creative audio features. And I listen to a lot of sound works, from people l've worked with in France, Spain and South America, as well as from well known outlets.

So this issue, as guest editor of RadioDoc Review, I invite YOU to send me your strongest audio work to be considered for an in-depth critique. I'm interested in intimate stories with a creative sound design: one that considers the placement, layering and interaction of sound, shows interesting transitions and composition and triggers audio's capacity to create pictures in the mind. The piece can be documentary, fiction or a sound essay, but it should have a strong narrative element - focused on personal story rather than an analysis of social issues.

There are a few rules. Works need to be:

- $\quad$ made after 1 January 2017

- 2-60mins duration

- submitted by 1 April 2018 (but sooner the better) 
- endorsed by an audio person of standing. That might be someone who's won a significant audio award, the manager of a radio station, or some other well credentialled audio professional. You can argue the case!

Please upload works as WAV to your preferred platform (e.g. Soundcloud) and send URL, summary of piece (150 words) and personal details including a 50-word bio to me at lauraromerovall@gmail.com. Works in languages other than Spanish or French need an English transcript.

Thanks! Merci! ¡Gracias!, and look forward to hearing some fresh, original work from all over.

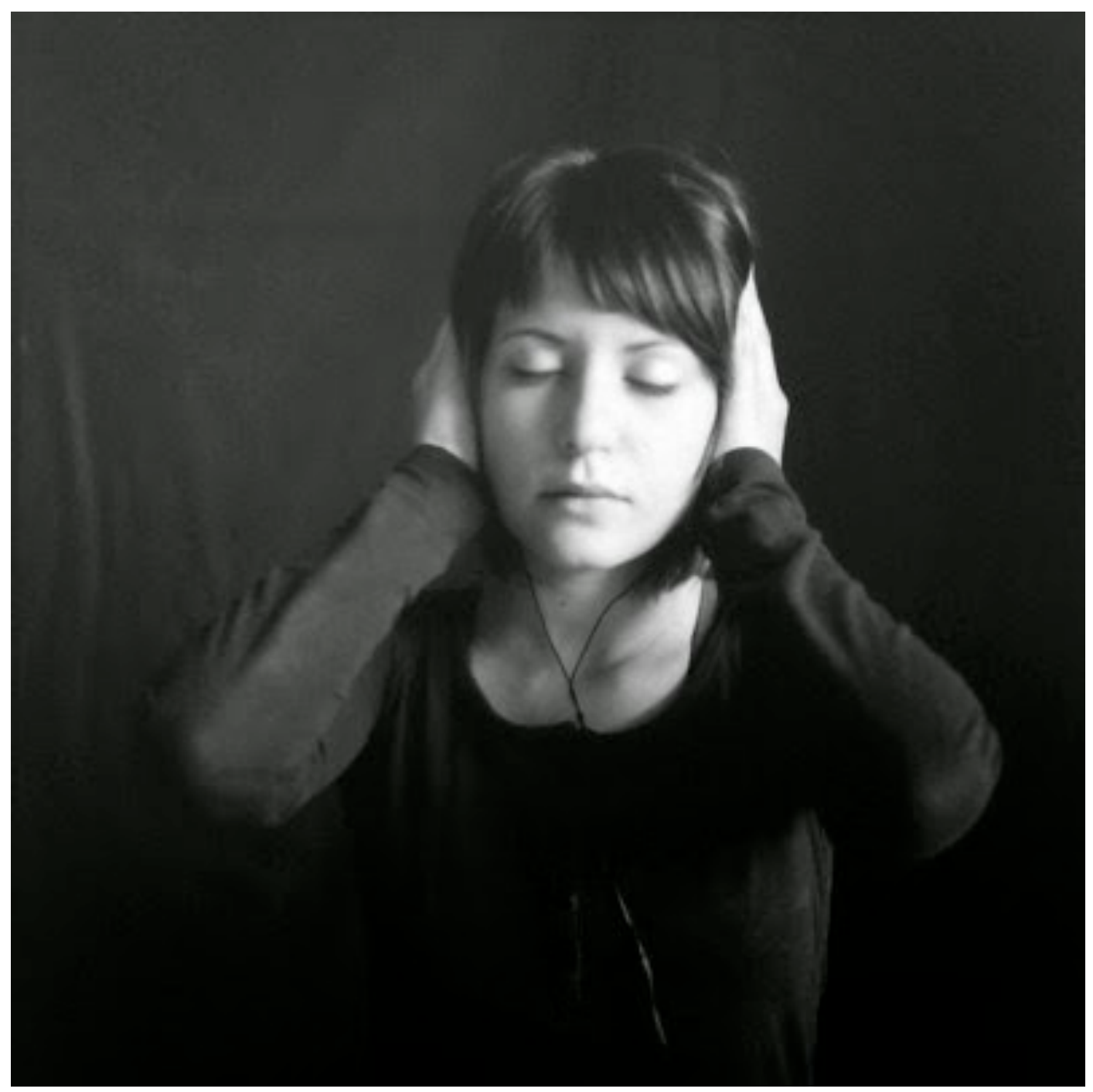

LAURA ROMERO (photo by Elisa Murcia Artengo)

\section{LAURA ROMERO}

www.laura-romero.com

www.radioimaginamos.org 